\title{
Editorial: Time Travel
}

\author{
PAUL RA E
}

One of the most forbidding and yet rewarding challenges in a substantive internationalization of arts scholarship is accounting for the experience and passage of time. The extent to which developments in theatre and performance over the past 150 years have been tied up with the larger social, economic and technological transformations reflexively understood as 'modernity' is a key reason an international journal readership is able to find interest and value in scholarship on performances they may not have seen, that are practised in places they have never been. At the same time, any such research - it is tempting to say 'from outside the West', but in fact the requirement holds everywhere - must register how the work under discussion complicates an otherwise oversimplified narrative of developmental modernity. This narrative treats a homogenized industrial and postindustrial 'West' as having led the way and established a model for how other parts of the world would modernize subsequently. The assumption is quickened in discussions of art because arguably one characteristic of those transformations as they happened in numerous centres of Euro-American power was the role that artists played in giving them aesthetic form and expressing their meanings. This is prominent in the emergence of modernism and the avant-garde, and it is logical that in recent times scholars of modernism have been particularly energetic in questioning the developmental narrative and demonstrating not only how such phenomena were constitutively reliant on processes elsewhere, but also how artistic developments everywhere both informed each other (often inequably) and manifested local and highly contingent characteristics.

A good example of such thinking is offered by Susan Stanford Friedman in her Planetary Modernisms, which seeks to consolidate the lessons of the many attempts to qualify modernisms as variously multiple, plural, discrepant, alternative, recurrent and so on, as well as to survey the critical value of a whole host of keywords that have been used to describe the ensuing intercultural dynamics. As broad theorizations go, Friedman's is both nuanced and expansive. Even so, the articles gathered in this issue present two notable riders to such a project. The first is that in spite of Friedman's accurate claim that '[e]very modernity has its distinctive modernism', artists, audiences and indeed critics are rarely concerned with larger-scale (and sometimes retrospectively applied) concepts like 'modernism' or 'modernity', even when seeking to place what they are doing or seeing within a discursive framework. ${ }^{1}$ The second is just how attentive and resourceful researchers therefore need to be in order to trace the ebb and flow of performance practices as they move in and out of the historical record, marking and inflecting it as they go. The variety and scope of such approaches are well illustrated by the articles and essays that make up this issue. 
In an enquiry stretching from the late nineteenth to the early twenty-first centuries, Yair Lipshitz's “This Is a Historical Israeli Play": Spectatorship, Ownership and the Israeli Localizations of Salomé establishes the temporal parameters of the issue as a whole, and points to some of the methodological principles required to address the events taking place within them. Although Oscar Wilde's Salomé was translated into Hebrew in 1906, only a little over a decade after it was written, the claim in Lipshitz's title, made by the translator of the play's first Israeli staging in 1982, is at once intriguing and provocative. Lipshitz uses the various historical and cultural appropriations, elisions and lacunae that such a claim enacts as a way into the complex interplay of seeing and knowing, desiring and describing at work within the play. This in turn forms the basis of a careful analysis of two Israeli productions that took place at very different moments in Israel's ongoing process of self-imaging and imagining (1982 and 2005), with accordingly divergent political and aesthetic agendas. Taking his cue from the figure of the title character to think about the fate of the play itself, Lipshitz concludes that 'among its many seductions, Salomé is ultimately a trap for Israeli culture, luring it with a promise of local landscape and history but in fact deeply engaged with displacement'. The challenge for researchers, we might add, is no less acute: knowing how to respond to the biographical, textual, aesthetic, theological, theatrical and archival layers that both obscure and reveal the play - and keep your head - is no easy task.

Theatrical negotiations over the relation between performance aesthetics and ideology against a backdrop of changing ideas about national identity are equally at issue in Siyuan Liu's 'Spoken Drama (Huaju) with a Strong Chinese Flavour'. Stretching from the 1910 s to the early 1960s, Liu's time frame is more concentrated than Lipshitz's, though the fact that there is a time frame worth speaking of is precisely Liu's point. His focus is a brief efflorescence in the late 1950 of of tongsu huaju, a form of popular spoken drama which emerged out of a hybrid of Western, Japanese and Chinese influences originally known as wenmingxi, and conventionally thought to have gone into decline in the 1920s, eclipsed by a more orthodox spoken drama form, huaju. Drawing on scripts and other documentation of performances, as well as criticism in books and journals by critics and practitioners, Liu pieces together both the works that comprised the tongsu huaju oeuvre and its fate in debates over aesthetic innovation and political utility. This highlights a distinctive moment in the history of Chinese theatre in the twentieth century, a period of liberalization just prior to the stringencies of the Cultural Revolution (196676). But, as Liu points out, it also raises questions about oversimplified periodizations not only in Chinese theatre, but also in the larger narratives that have sought to explain the developments of 'Asian' theatre over the course of the twentieth century.

Such developmental questions also lie at the heart of C. J. Wee Wan-ling's examination of what he calls the 'ordinary' art of Singaporean performance artist Tang $\mathrm{Da} \mathrm{Wu}$ (b. 1943). There, the 'developmentalism' at issue is that of the South East Asian city state to which Tang returned in 1987, after a period living in England. Singapore was in the throes of rapid and far-reaching economic and urban expansion at the time, and Wee reads Tang's oeuvre as a highly distinctive response. Aesthetically modest, almost insouciantly inventive, and deeply engaged with the capacity of performance to foster community and opportunities for pedagogy, Tang's work goes against the grain of the 
heroic image of the performance artist enacting feats of individual endurance that has captured the imagination in much public discourse. At the same time, Wee sees Tang's work not so much as a repudiation of an equally 'heroic' Asian modernity, than as a means of disclosing its meanings and effects as they have manifested themselves at the level of the mundane, in lived experience. Wee reflects such an approach in his own method, by treating Tang's oeuvre as a whole - one that has taken different forms at different times, but that has nevertheless been consistently marked by Tang's own unassuming (though far from guileless) personality.

By comparison with the preceding articles, Kirsty Sedgman's 'Audience Experience in an Anti-expert Age' takes up an issue that is in some regards all too contemporary. The year 2016 saw the crystallization, in political discourse in the UK, the US and elsewhere, of 'anti-expert' attitudes: a posture that ultimately contributed to the UK's decision to leave the European Union and the success of Donald Trump's presidential campaign in the US. Rightly circumspect about the use of 'anti-expert' rhetoric by populist politicians, Sedgman nevertheless recognizes in it a particular challenge for those researchers who would wish to contest the delegitimization of expertise, and are at the same time committed to expanding the definition of cultural value by factoring in public responses to, and perceptions of, the arts more fully. Noting that the rise of anti-expert rhetoric has coincided with numerous institutional efforts to consolidate the growing interest in theatre audience research, Sedgman historicizes this approach, surveys current methodologies and anticipates future research directions. In so doing, she notes a degree of scepticism towards audience research from some working within the cultural domain, who fear that it may lead to an instrumentalized and 'dumbed-down' approach to creativity. But this, argues Sedgman, is itself an oversimplification of what a properly attentive (and ultimately expertly informed) approach to audience experience is able to disclose about theatre's meanings and effects.

Finally, a cluster of essays by three emerging Indian scholars - Manjari Mukherjee, Indu Jain and Promona Sengupta - reproduces the scope of the issue as a whole by spanning a range of moments in twentieth-century history, and tying them in with questions of gender and citizenship, performance and social class. As Bishnupriya Dutt explains in her introduction, the essays emerged out of Gendered Citizenship, a collaborative research project by an interdisciplinary group of scholars from Jawaharlal Nehru University in New Delhi, and the University of Warwick in the UK. As such, each of the essays is preoccupied with how theatre has been practised within educational contexts to reflect on the role of the citizen - particularly, though not exclusively, women - against the background of changing ideas about national identity on the one hand and theatre aesthetics on the other. I will not preview here the content of the essays, which is ably provided by Dutt in her introduction to the cluster. I would instead note, in light of the remarks with which I began this editorial, how much of a work-in-process the recovery and nuancing of the role of performance in the experience of modernity continues to be. As emerging scholars, Mukherjee, Jain and Sengupta exemplify the desire to look ahead to how their intellectual endeavours might improve conditions in their home city and nation even as they look 'back' in order to understand how the present came to be as it is. Taken as a whole, the cluster encompasses archival research, 
interview transcripts, performance analysis and participant observation to recount and reflect on several telling episodes in the history of post-independence Indian theatre. I am very grateful to Manjari, Indu and Promona, as well as to Bishnupriya, for their tireless commitment to seeing their work through an exhaustive editorial process and into print.

Lastly, I was also thrilled to see that the group found inspiration in Partha Chatterjee's article 'Theatre and the Public of Democracy', which appeared in issue 41, 3 of Theatre Research International, last year. Since the editorship of this journal only lasts three years, it is not always possible to register such a fast 'turnaround' in the impact of work one has seen through to publication. Hearing an article from the first issue I edited (Adele Senior's 'Beginners On Stage', from 41, 1) being productively cited in a recent conference paper further enhanced my appreciation for both the authors and readers of this journal. Such take-up of ideas in subsequent work underscores the role that critical discourse itself plays in the recursive and multifaceted project of understanding modernity, internationally, with which this journal is centrally concerned, and to which this issue now makes its own contribution.

NOTE

1 Susan Stanford Friedman, Planetary Modernisms: Provocations on Modernity across Time (New York:

Columbia University Press, 2015), p. 53. 